\title{
Genetic Association between Presenilin 2 Polymorphisms and Alzheimer's Disease and Dementia of Lewy Body Type in a Japanese Population
}

\author{
Ayako Suzuki $^{a}$ Nobuto Shibata ${ }^{a}$ Koji Kasanuki ${ }^{a}$ Tomoyuki Nagatac, d \\ Shunichiro Shinagawa ${ }^{c}$ Nobuyuki Kobayashic Tohru Ohnuma ${ }^{\mathrm{a}}$ \\ Yoshihide Takeshita $^{a}$ Eri Kawai ${ }^{a}$ Toshiki Takayama ${ }^{a}$ Kenya Nishiokab \\ Yumiko Motoi $^{\mathrm{b}}$ Nobutaka Hattori ${ }^{\mathrm{b}}$ Kazuhiko Nakayamac \\ Hisashi Yamada ${ }^{d}$ Heii Arai ${ }^{a}$ \\ Departments of a Psychiatry and ${ }^{b}$ Neurology, Juntendo University School of Medicine, and \\ 'Department of Psychiatry, and d Division of Molecular Genetics, Institute of DNA Medicine, \\ Jikei University School of Medicine, Tokyo, Japan
}

Key Words

Presenilin 2 - Apolipoprotein E - Single nucleotide polymorphism - Alzheimer's disease · Lewy body dementia

\begin{abstract}
Background/Aims: Mutations in the presenilin 2 (PSEN2) gene cause familial Alzheimer's disease (AD). Common polymorphisms affect gene activity and increase the risk of AD. Nonsynonymous polymorphisms in the PSEN2 gene showed Lewy body dementia (LBD) phenotypes clinically. Therefore, we aimed to investigate whether PSEN2 gene polymorphisms were associated with AD or LBD. Methods: Seven single nucleotide polymorphisms (SNPs) of the gene were analyzed using a case-control study design comprising 288 AD patients, 76 LBD patients, and 105 age-matched controls. Results: Linkage disequilibrium (LD) examination showed strong LD from rs 1295645 to rs8383 on the gene in our cases from Japan. There were no associations between the SNPs studied here and AD onset, and haplotypic analyses did not detect genetic associations between AD and the PSEN2 gene. Although the number of the cases was small, the SNPs studied did not modify the risk of developing LBD in a Japanese population. Conclusion: The common SNPs of the PSEN2 gene did not affect the risk of AD or LBD in a Japanese population. Because genetic variability of the PSEN2 gene is associated with behavioral and psychological symptoms of dementia (BPSD) in AD and LBD, further detailed analyses considering BPSD of both diseases would be required.
\end{abstract}




\section{Introduction}

Alzheimer's disease (AD) is the most common neurodegenerative disease. Genetic, metabolic, and environmental factors play an important role in the pathophysiology of sporadic AD. Presenilins are the catalytic components of the gamma-secretase complex and play an important role in the amyloid $\beta(\mathrm{A} \beta)$ cascade in $\mathrm{AD}$ [1]. Presenilin 1 (PSEN1) gene mutations on chromosome 14q24.3 cause autosomal dominant early-onset familial AD [1, 2]. The presenilin 2 (PSEN2) gene on chromosome 1q31-q42 is a homolog of the PSEN1 gene and shares $62 \%$ amino acid identity $[1,2]$. Although PSEN2 gene mutations are additionally reported to cause familial AD, pathogenic PSEN2 gene mutations are rare [3]. Among the genetic risk factors, the apolipoprotein E (APOE) is recognized as an established genetic risk factor for sporadic AD [2]. Riazanskaia et al. [4] showed that the $5^{\prime}$ regulatory region polymorphisms in the PSEN2 gene contribute to the gene activity and risk of sporadic AD. The single nucleotide polymorphism (SNP) rs8383 on the $3^{\prime}$ untranslated region of the gene was additionally analyzed in sporadic AD [5]. Although a few replication studies have been performed, it is currently unknown whether PSEN2 gene polymorphisms contribute to the incidence of sporadic AD.

Lewy body dementia (LBD) is the second most common human neurodegenerative disease after AD. The pathological features of LBD are the deposition of $\alpha$-synuclein in Lewy bodies and the presence of Lewy neurites in the brainstem, limbic, and cortical areas [6]. Most LBD cases show varying degrees of concurrent $A \beta$ pathology, and several lines of evidence indicate that $\mathrm{A} \beta$ and $\alpha$-synuclein may interact with each other [7, 8]. A $\beta$ deposits could cause local aggregation of $\alpha$-synuclein $[9,10]$. In contrast to $A D$, genetic studies for both familial and sporadic LBD have not been completely established [11]. The PSEN1 mutations enhance the pathogenic phosphorylation and aggregation of $\alpha$-synuclein in vivo and in vitro $[12,13]$. Certain nonsynonymous PSEN2 gene polymorphisms have clinically shown LBD or LBD-like phenotypes [3, 14]. Few studies have reported associations between the PSEN1 gene and LBD, and to the best of our knowledge, there are no association studies for PSEN2 and the disease [15]. In the present study, we aimed to elucidate whether PSEN2 gene polymorphisms affect AD and LBD.

\section{Materials and Methods}

Sporadic Japanese AD cases were diagnosed according to the National Institute of Neurological and Communicative Disorders and Stroke and the Alzheimer's Disease and Related Disorders Association (NINCDS-ADRDA) criteria, and none of them had a familial history of AD [16]. AD cases were obtained from the Department of Psychiatry, Juntendo University Hospital; the Department of Psychiatry, Juntendo Koshigaya Hospital; the Department of Psychiatry, Jikei University Hospital, and the Department of Psychiatry, Jikei Kashiwa Hospital. LBD cases from Japan consisted of two groups: (1) LBD cases that were recruited from the PET/CT Dementia Research Center, Juntendo Tokyo Koto Geriatric Medical Center according to the diagnostic criteria by McKeith et al. [17] and (2) patients of Parkinson's disease with dementia who were recruited from the Department of Neurology, Juntendo University Hospital according to the diagnostic criteria by Emre et al. [18]. Healthy volunteers among our hospital staff with no history of dementia or other neuropsychiatric diseases were included as control cases.

The purpose and significance of the current study was explained in detail in writing, including verbal supplementation as required, to each patient. All subjects provided their written informed consent. The study protocols were approved by the Ethics Committee of both the Juntendo University School of Medicine and the Jikei University School of Medicine. 
Table 1. Subjects of the study

Fig. 1. Genetic location of the six PSEN2 SNPS.

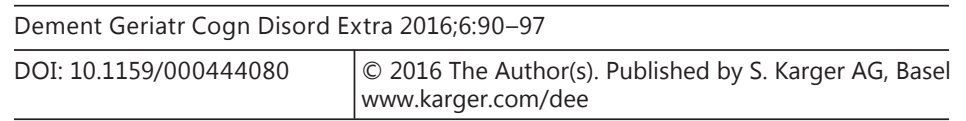

Suzuki et al.: Genetic Association between Presenilin 2 Polymorphisms and Alzheimer's Disease and Dementia of Lewy Body Type in a Japanese Population

\begin{tabular}{llll}
\hline & $\begin{array}{l}\text { Number } \\
\text { (male:female) }\end{array}$ & $\begin{array}{l}\text { Age, years } \\
(\text { mean } \pm \text { SD) }\end{array}$ & $\begin{array}{l}\text { APOE } \varepsilon 4 \text {-positive } \\
\text { cases, n (\%) }\end{array}$ \\
\hline AD & $288(123: 165)$ & $69.6 \pm 9.1$ & $134(46.5)$ \\
LBD & $76(42: 34)$ & $70.7 \pm 9.1$ & $20(26.3)$ \\
Controls & $105(44: 61)$ & $68.1 \pm 5.1$ & $24(22.9)$ \\
\hline
\end{tabular}

Genetic location of the six PSEN2 SNPs

Table 1 shows the details of the subjects in our case-control study. The mean ages of the three groups showed no statistically significant differences. DNA was extracted from white blood cells using a standard method. Seven SNPs on the PSEN2 gene, i.e., rs1295645, rs2073489, rs11405, rs6759, rs1046240, rs1800680, and rs8383, were genotyped using TaqMan technology on an ABI7500 system (Applied Biosystems, Foster City, Calif., USA). Probes and primers were designed by the Assay-by-Design TM service of Applied Biosystems. A standard polymerase chain reaction (PCR) was performed using the TaqMan Universal PCR Master Mix reagent kit with a 10- $\mu$ l volume. APOE genotypes for all the samples were determined according to a previous report [19].

\section{Statistical Analyses for Genetic Data}

Differences in the genotypic and allelic frequencies of each SNP were evaluated using a case-control study design and statistical comparison with Fisher's exact test. Linkage disequilibrium (LD) between SNPs was analyzed, and haplotype analyses were performed. LD, denoted as $\mathrm{D}^{\prime}$, was calculated from the haplotype frequency using the expectation-maximization algorithm. SNPs were considered to be in $\mathrm{LD}$ if $\mathrm{D}^{\prime}$ was $>0.75$. A case-control haplotype analysis was performed using a permutation method to obtain the empirical significance. The global $p$ values represent the overall significance of the observed versus expected frequencies of all the haplotypes considered together using the $\chi^{2}$ test. The individual haplotypes were tested for association by grouping all others together and applying the $\chi^{2}$ test with one degree of freedom. $p$ values were calculated on the basis of 10,000 replications. All the p values reported are two tailed, and statistical significance was defined as $p<0.05$. Because the number of LBD cases was small, we could not perform haplotype analysis for LBD. HardyWeinberg equilibrium tests were performed in whole cases. Those analyses were performed using SNPAlyse version 7.0 Pro (Dynacom, Chiba, Japan).

\section{Results}

We performed power calculations for our AD control subjects using the power calculator (http://www.sph.umich.edu/csg/abecasis/CaTS/). Power was calculated under the prevalence of 0.10 using an additive or a multiplicative model based on allelic frequencies of 0.20 with an odds ratio of 1.50 and an alpha level of 0.05 . Results for power analyses demon- 
Table 2. Genotypic and allelic frequencies of SNPs of the PSEN2 gene

\begin{tabular}{|c|c|c|c|c|c|c|c|c|c|c|}
\hline SNPs & $\begin{array}{l}\text { Geno- } \\
\text { type }\end{array}$ & $\mathrm{AD}$ & Controls & & Allele & $\mathrm{AD}$ & Controls & & $\begin{array}{l}\text { Odds ratio } \\
(95 \% \mathrm{CI})\end{array}$ & $\begin{array}{l}\text { HWE } \\
\text { (whole } \\
\text { cases) }\end{array}$ \\
\hline \multirow[t]{3}{*}{ rs1295645 } & $\mathrm{C} / \mathrm{C}$ & $208(0.72)$ & $70(0.67)$ & & $\mathrm{C}$ & $491(0.85)$ & $172(0.82)$ & & & \\
\hline & $\mathrm{C} / \mathrm{T}$ & $75(0.26)$ & $32(0.30)$ & $\chi^{2}=0.37$ & $\mathrm{~T}$ & $85(0.15)$ & $38(0.18)$ & $\chi^{2}=1.30$ & $1.27(0.82-1.94)$ & $\chi^{2}=0.004$ \\
\hline & $\mathrm{T} / \mathrm{T}$ & $5(0.02)$ & $3(0.03)$ & $\mathrm{p}=0.44$ & & & & $\mathrm{p}=0.25$ & & $\mathrm{p}=0.86$ \\
\hline \multirow[t]{3}{*}{ rs2073489 } & $\mathrm{C} / \mathrm{C}$ & $82(0.28)$ & $25(0.24)$ & 0 & $\mathrm{C}$ & $284(0.49)$ & $106(0.50)$ & & & \\
\hline & $\mathrm{C} / \mathrm{T}$ & $120(0.42)$ & $56(0.53)$ & $\chi^{2}=5.62$ & $\mathrm{~T}$ & $292(0.51)$ & $104(0.50)$ & $\chi^{2}=0.10$ & $0.95(0.70-1.30)$ & $\chi^{2}=2.61$ \\
\hline & $\mathrm{T} / \mathrm{T}$ & $86(0.30)$ & $24(0.23)$ & $\mathrm{p}=0.07$ & & & & $\mathrm{p}=0.75$ & & $\mathrm{p}=0.10$ \\
\hline \multirow[t]{3}{*}{ rs11405 } & $\mathrm{C} / \mathrm{C}$ & $143(0.50)$ & $48(0.46)$ & & $\mathrm{C}$ & $405(0.70)$ & $139(0.66)$ & & & \\
\hline & $\mathrm{C} / \mathrm{T}$ & $119(0.41)$ & $43(0.41)$ & $\chi^{2}=1.65$ & $\mathrm{~T}$ & $171(0.30)$ & $71(0.34)$ & $\chi^{2}=1.23$ & $1.21(0.84-1.71)$ & $\chi^{2}=0.07$ \\
\hline & $\mathrm{T} / \mathrm{T}$ & $26(0.09)$ & $14(0.13)$ & $\mathrm{p}=0.43$ & & & & $\mathrm{p}=0.27$ & & $\mathrm{p}=0.73$ \\
\hline \multirow[t]{3}{*}{ rs6759 } & $\mathrm{C} / \mathrm{C}$ & $84(0.29)$ & $25(0.24)$ & & $\mathrm{C}$ & $286(0.50)$ & $107(0.51)$ & & & \\
\hline & $\mathrm{C} / \mathrm{T}$ & $118(0.41)$ & $57(0.54)$ & $\chi^{2}=5.70$ & $\mathrm{~T}$ & $290(0.50)$ & $103(0.49)$ & $\chi^{2}=0.11$ & $0.96(0.71-1.31)$ & $\chi^{2}=2.92$ \\
\hline & $\mathrm{T} / \mathrm{T}$ & $86(0.30)$ & $23(0.22)$ & $p=0.06$ & & & & $\mathrm{p}=0.75$ & & $\mathrm{p}=0.07$ \\
\hline \multirow[t]{3}{*}{ rs1046240 } & $\mathrm{C} / \mathrm{C}$ & $83(0.29)$ & $26(0.25)$ & & $\mathrm{C}$ & $285(0.49)$ & $108(0.51)$ & & & \\
\hline & $\mathrm{C} / \mathrm{T}$ & $119(0.41)$ & $56(0.53)$ & $\chi^{2}=5.25$ & $\mathrm{~T}$ & $291(0.51)$ & $102(0.49)$ & $\chi^{2}=0.15$ & $0.98(0.73-1.32)$ & $\chi^{2}=2.90$ \\
\hline & $\mathrm{T} / \mathrm{T}$ & $86(0.30)$ & $23(0.22)$ & $\mathrm{p}=0.07$ & & & & $\mathrm{p}=0.71$ & & $\mathrm{p}=0.09$ \\
\hline \multirow[t]{3}{*}{ rs8383 } & $\mathrm{C} / \mathrm{C}$ & $84(0.29)$ & $25(0.24)$ & & $\mathrm{C}$ & $284(0.49)$ & $107(0.51)$ & & & \\
\hline & $\mathrm{C} / \mathrm{T}$ & $116(0.40)$ & $57(0.54)$ & $\chi^{2}=5.56$ & $\mathrm{~T}$ & $292(0.51)$ & $103(0.49)$ & $\chi^{2}=0.14$ & $0.96(0.72-1.31)$ & $\chi^{2}=3.58$ \\
\hline & $\mathrm{T} / \mathrm{T}$ & $88(0.31)$ & $23(0.22)$ & $\mathrm{p}=0.07$ & & & & $\mathrm{p}=0.70$ & & $p=0.06$ \\
\hline SNPS & $\begin{array}{l}\text { Geno- } \\
\text { type }\end{array}$ & LBD & Controls & & Allele & LBD & Controls & & $\begin{array}{l}\text { Odds ratio } \\
(95 \% \mathrm{CI})\end{array}$ & \\
\hline \multirow[t]{3}{*}{ rs1295645 } & $\mathrm{C} / \mathrm{C}$ & $55(0.72)$ & $70(0.67)$ & & $\mathrm{C}$ & $127(0.84)$ & $172(0.82)$ & & & \\
\hline & $\mathrm{C} / \mathrm{T}$ & $17(0.22)$ & $32(0.30)$ & $\chi^{2}=1.94$ & $\mathrm{~T}$ & $25(0.16)$ & $38(0.18)$ & $\chi^{2}=0.17$ & $0.89(0.49-1.54)$ & \\
\hline & $\mathrm{T} / \mathrm{T}$ & $4(0.06)$ & $3(0.03)$ & $\mathrm{p}=0.42$ & & & & $\mathrm{p}=0.69$ & & \\
\hline \multirow[t]{3}{*}{ rs2073489 } & $\mathrm{C} / \mathrm{C}$ & $18(0.24)$ & $25(0.24)$ & & $\mathrm{C}$ & $77(0.51)$ & $106(0.50)$ & & & \\
\hline & $\mathrm{C} / \mathrm{T}$ & $41(0.54)$ & $56(0.53)$ & $\chi^{2}=0.05$ & $\mathrm{~T}$ & $75(0.49)$ & $104(0.50)$ & $\chi^{2}=0.03$ & $1.01(0.68-1.54)$ & \\
\hline & $\mathrm{T} / \mathrm{T}$ & $17(0.22)$ & $24(0.23)$ & $\mathrm{p}=0.99$ & & & & $\mathrm{p}=0.99$ & & \\
\hline \multirow[t]{3}{*}{ rs11405 } & $\mathrm{C} / \mathrm{C}$ & $38(0.50)$ & $48(0.46)$ & & $\mathrm{C}$ & $109(0.72)$ & $139(0.66)$ & & & \\
\hline & $\mathrm{C} / \mathrm{T}$ & $33(0.43)$ & $43(0.41)$ & $\chi^{2}=2.15$ & $\mathrm{~T}$ & $43(0.28)$ & $71(0.34)$ & $\chi^{2}=1.25$ & $0.77(0.49-1.23)$ & \\
\hline & $\mathrm{T} / \mathrm{T}$ & $5(0.07)$ & $14(0.13)$ & $\mathrm{p}=0.15$ & & & & $\mathrm{p}=0.26$ & & \\
\hline \multirow[t]{3}{*}{ rs6759 } & $\mathrm{C} / \mathrm{C}$ & $18(0.24)$ & $25(0.24)$ & & $\mathrm{C}$ & $76(0.50)$ & $107(0.51)$ & & & \\
\hline & $\mathrm{C} / \mathrm{T}$ & $40(0.52)$ & $57(0.54)$ & $\chi^{2}=0.08$ & $\mathrm{~T}$ & $76(0.50)$ & $103(0.49)$ & $\chi^{2}=0.03$ & $1.04(0.68-1.60)$ & \\
\hline & $\mathrm{T} / \mathrm{T}$ & $18(0.24)$ & $23(0.22)$ & $\mathrm{p}=0.98$ & & & & $\mathrm{p}=0.86$ & & \\
\hline \multirow[t]{3}{*}{ rs 1046240} & $\mathrm{C} / \mathrm{C}$ & $18(0.24)$ & $26(0.25)$ & & $\mathrm{C}$ & $76(0.50)$ & $108(0.51)$ & & & \\
\hline & $\mathrm{C} / \mathrm{T}$ & $40(0.52)$ & $56(0.53)$ & $\chi^{2}=0.09$ & $\mathrm{~T}$ & $76(0.50)$ & $102(0.49)$ & $\chi^{2}=0.04$ & $1.06(0.70-1.58)$ & \\
\hline & $\mathrm{T} / \mathrm{T}$ & $18(0.24)$ & $23(0.22)$ & $p=0.96$ & & & & $\mathrm{p}=0.84$ & & \\
\hline \multirow[t]{3}{*}{ rs8383 } & $\mathrm{C} / \mathrm{C}$ & $19(0.25)$ & $25(0.24)$ & & $\mathrm{C}$ & $77(0.51)$ & $107(0.51)$ & & & \\
\hline & $\mathrm{C} / \mathrm{T}$ & $39(0.51)$ & $57(0.54)$ & $\chi^{2}=0.07$ & $\mathrm{~T}$ & $75(0.49)$ & $103(0.49)$ & $\chi^{2}=0.01$ & $1.02(0.55-1.56)$ & \\
\hline & $\mathrm{T} / \mathrm{T}$ & $18(0.24)$ & $23(0.22)$ & $\mathrm{p}=0.99$ & & & & $\mathrm{p}=0.99$ & & \\
\hline
\end{tabular}

$\mathrm{CI}=$ Confidence interval; HWE $=$ Hardy-Weinberg equilibrium.

strated that the power ranged from $65 \%$ for the additive model to $72 \%$ for the multiplicative model.

SNP rs1800680 was not polymorphic in our cases from Japan. Figure 1 shows the genetic location of the studied SNPs. The six SNPs of the PSEN2 gene were found to be located using Hardy-Weinberg equilibrium. LD examination showed strong LD from rs1295645 to rs8383 on the gene in our cases from Japan (table 2).

The genotypic frequencies of the six SNPs of the PSEN2 gene are shown in table 3. There was no statistical difference between AD cases and controls for all SNPs in genotypes and alleles. The comparison between LBD and control cases also showed no statistically significant differences. The haplotypic frequencies of the AD group did not differ from those of controls (table 4). 
Suzuki et al:: Genetic Association between Presenilin 2 Polymorphisms and Alzheimer's

Table 3. $\mathrm{D}^{\prime}$ values between the SNPs of the PSEN2 gene (whole cases)

\begin{tabular}{|c|c|c|c|c|c|c|}
\hline & $\begin{array}{l}\text { rs1295645 } \\
(\mathrm{C} / \mathrm{T})\end{array}$ & $\begin{array}{l}\text { rs2073489 } \\
(\mathrm{C} / \mathrm{T})\end{array}$ & $\begin{array}{l}\text { rs11405 } \\
(\mathrm{C} / \mathrm{T})\end{array}$ & $\begin{array}{l}\text { rs6759 } \\
(\mathrm{C} / \mathrm{T})\end{array}$ & $\begin{array}{l}\text { rs1046240 } \\
(\mathrm{C} / \mathrm{T})\end{array}$ & $\begin{array}{l}\text { rs8383 } \\
(\mathrm{C} / \mathrm{T})\end{array}$ \\
\hline \multicolumn{7}{|l|}{ rs1295645 (C/T) } \\
\hline rs2073489 $(\mathrm{C} / \mathrm{T})$ & -0.9663 & & & & & \\
\hline rs11405 $(\mathrm{C} / \mathrm{T})$ & 0.9803 & -0.9859 & & & & \\
\hline $\operatorname{rs6759}(\mathrm{C} / \mathrm{T})$ & -0.9663 & 1 & -0.9859 & & & \\
\hline rs1046240 $(\mathrm{C} / \mathrm{T})$ & -0.9663 & 1 & -0.9859 & 1 & & \\
\hline rs8383 (C/T) & 0.9012 & -1 & 0.9582 & -1 & 0.9932 & \\
\hline
\end{tabular}

Numbers in italic font indicate statistical significance.

Table 4. A case-control haplotype analysis for the six PSEN2 SNPs for AD and controls

\begin{tabular}{lllll}
\hline Haplotype & Overall & AD & Control & $\begin{array}{l}\text { Permutation } \\
\text { p value }\end{array}$ \\
\hline C-T-C-T-T-T & 0.50 & 0.50 & 0.49 & 0.82 \\
C-C-C-C-C-C & 0.19 & 0.20 & 0.17 & 0.42 \\
C-C-T-C-C-C & 0.15 & 0.15 & 0.16 & 0.91 \\
T-C-T-C-C-C & 0.15 & 0.14 & 0.18 & 0.13 \\
\hline
\end{tabular}

Rare haplotypes with frequencies $>5 \%$ are not shown. Each nucleotide on the haplotypes represents SNPs in the following order from left to right: rs1295645, rs2073489, rs11405, rs6759, rs1046240, and rs8383.

\section{Discussion}

\section{Alzheimer's Disease}

To date, several genetic association studies between AD and the PSEN2 gene have been described. After the reports of Riazanskaia et al. [4] using cases from Russia, polymorphisms on the 5' promoter region of the PSEN2 gene were examined within several populations. Both positive and negative results were reported for regulatory region variants [20-23]. Three studies using cases from Japan have been performed to date [24-26]. These previous reports have tested whether $5^{\prime}$ promoter, intronic, and exonic polymorphisms on the gene affect the risk of AD. The results of the current study are consistent with those of these previous three reports. No synergetic associations were found among SNPs, APOE, and the risk of AD (data not shown). However, one association study in a Han Chinese population has shown that the promoter region insertion/deletion polymorphism could be a moderate genetic risk factor for AD [27]. The meta-analytic study suggested that the insertion/deletion polymorphism did not affect AD risk [5]. A specific haplotype with four tagging SNPs (rs2073489, rs11405, rs6759, and rs1800680) of the PSEN2 gene was found to be functionally correlated with cerebrospinal fluid A $\beta 42$ among German patients [28]. Although rs1800680 was not polymorphic, our haplotype analyses with these tagging SNPs were found not to modify the risk of developing AD in the Japanese population.

Replication studies of the SNP rs8383 have been previously performed [5, 29]. The abovementioned meta-analysis for rs8383 showed that the polymorphism is associated with a heightened risk of AD [5]. Significant associations for the polymorphism were not detected in the current study. Our results showed that the polymorphism was in LD to the same degree 
Suzuki et al.: Genetic Association between Presenilin 2 Polymorphisms and Alzheimer's Disease and Dementia of Lewy Body Type in a Japanese Population

as in other SNPs and that the haplotype including rs8383 did not affect the disease within a Japanese population. The conflicting results among studies are probably indicative of genetic and ethnic heterogeneity of AD. Zhang et al. [30] have reported the influence of rs6759 and rs11405 on mRNA expression in blood lymphocytes from patients with schizophrenia. They additionally reported that rs 1295645 was associated with the psychotic symptoms of patients with schizophrenia [30]. These results suggested that SNPs on the PSEN2 gene may affect the risk of AD with such symptoms. To clarify associations between polymorphisms and AD, further studies incorporating the measurements of behavioral and psychological symptoms of dementia would be required.

\section{Lewy Body Dementia}

This is the first pilot study to clarify the genetic associations between the common SNPs of the PSEN2 gene and LBD in a Japanese population. Although haplotypic analyses were not performed, because of the small number of cases, we failed to show a genetic association between the six SNPs and the onset of the disease. Genetic studies for LBD were not completely performed and did not detect strong risk genes such as APOE4 in AD [11,31]. Mixed pathologies with AD and LBD are crucial, and our LBD-control cohort could not show any associations between LBD and APOE4. We additionally examined whether genotypic and allelic frequencies of the six SNPs of AD cases differ from those of LBD cases and did not identify any significant differences (data not shown).

Jayadev et al. [14] reported the phenotypes of cases with the N141I mutation of the PSEN2 gene. The typical mutation was found in Volga German families and is known to affect the $A \beta$ pathology. Most cases were accompanied by $\alpha$-synuclein pathology in amygdala as revealed by brain autopsies. These findings suggested that genetic variability of the PSEN2 gene plays an important role for mixed pathology, AD, and LBD. Other mutations, such as $\mathrm{R} 62 \mathrm{H}$ and A85V, were additionally known to present peculiar clinical features of LBD [32,33]. Cases with M239V mutation also indicate focal dysfunction of the posterior cortical areas, resembling the more extended parieto-occipitotemporal dysfunction [34]. In addition to cognitive symptoms, characteristic clinical phenotypes of N141I mutation were reported. Hallucinations, delusions, or psychotic symptoms were found in one third of the affected patients with the mutation $[3,14]$. There are few past association studies for common polymorphisms in the gene and behavioral and psychological symptoms of LBD. Detailed investigation PSEN2 gene polymorphisms in LBD cases showing such symptoms would result in a better understanding of the gene and LBD.

\section{Acknowledgments}

This study was partially supported by the High Technology Research Center Grant from the Ministry of Education, Culture, Sports, Science and Technology of Japan and by the Sportology Center, Juntendo University Graduate School of Medicine. We are grateful for the technical assistance of K. Yamamoto and Y. Li.

\section{References}

1 St George-Hyslop PH: Molecular genetics of Alzheimer's disease. Biol Psychiatry 2000;47:183-199.

$\rightarrow 2$ Rogaeva E: The solved and unsolved mysteries of the genetics of early-onset Alzheimer's disease. Neuromolecular Med 2002;2:1-10.

-3 Canevelli M, Piscopo P, Talarico G, Vanacore N, Blasimme A, Crestini A, Tosto G, Troili F, Lenzi GL, Confaloni A, Bruno G: Familial Alzheimer's disease sustained by presenilin 2 mutations: systematic review of literature and genotype-phenotype correlation. Neurosci Biobehav Rev 2014;42:170-179. 
-4 Riazanskaia N, Lukiw WJ, Grigorenko A, Korovaitseva G, Dvoryanchikov G, Moliaka Y, Nicolaou M, Farrer L, Bazan NG, Rogaev E: Regulatory region variability in the human presenilin-2 (PSEN2) gene: potential contribution to the gene activity and risk for AD. Mol Psychiatry 2002;7:891-898.

-5 Chen C, Zhou Z, Li M, Qu M, Ma Q, Zhong M, Zhang Y, Yu Z: Presenilin-2 polymorphisms and risk of sporadic AD: evidence from a meta-analysis. Gene 2012;503:194-199.

-6 Lee HJ, Bae EJ, Lee SJ: Extracellular alpha-synuclein - a novel and crucial factor in Lewy body diseases. Nat Rev Neurol 2014;10:92-98.

7 Clinton LK, Blurton-Jones M, Myczek K, Trojanowski JQ, LaFerla FM: Synergistic Interactions between Abeta, tau, and alpha-synuclein: acceleration of neuropathology and cognitive decline. J Neurosci 2010;30:72817289.

-8 Leverenz JB, Fishel MA, Peskind ER, Montine TJ, Nochlin D, Steinbart E, Raskind MA, Schellenberg GD, Bird TD, Tsuang D: Lewy body pathology in familial Alzheimer disease: evidence for disease- and mutation-specific pathologic phenotype. Arch Neurol 2006;63:370-376.

-9 Larson ME, Sherman MA, Greimel S, Kuskowski M, Schneider JA, Bennett DA, Lesné SE: Soluble alpha-synuclein is a novel modulator of Alzheimer's disease pathophysiology. J Neurosci 2012;32:10253-10266.

10 Resende R, Marques SC, Ferreiro E, Simoes I, Oliveira CR, Pereira CM: Effect of alpha-synuclein on amyloid beta-induced toxicity: relevance to Lewy body variant of Alzheimer disease. Neurochem Res 2013;38:797806.

11 Meeus B, Theuns J, Van Broeckhoven C: The genetics of dementia with Lewy bodies: what are we missing? Arch Neurol 2012;69:1113-1118.

-12 Snider BJ, Norton J, Coats MA, Chakraverty S, Hou CE, Jervis R, Lendon CL, Goate AM, McKeel DW Jr, Morris JC: Novel presenilin 1 mutation (S170F) causing Alzheimer disease with Lewy bodies in the third decade of life. Arch Neurol 2005;62:1821-1830.

13 Winslow AR, Moussaud S, Zhu L, Post KL, Dickson DW, Berezovska O, McLean PJ: Convergence of pathology in dementia with Lewy bodies and Alzheimer's disease: a role for the novel interaction of alpha-synuclein and presenilin 1 in disease. Brain 2014;137:1958-1970.

14 Jayadev S, Leverenz JB, Steinbart E, Stahl J, Klunk W, Yu CE, Bird TD: Alzheimer's disease phenotypes and genotypes associated with mutations in presenilin 2. Brain 2010;133:1143-1154.

15 Singleton AB, Lamb H, Leake A, McKeith IG, Ince PG, Perry RH, Morris CM: No association between a polymorphism in the presenilin 1 gene and dementia with Lewy bodies. Neuroreport 1997;8:3637-3639.

-16 McKhann G, Drachman D, Folstein M, Katzman R, Price D, Stadlan EM: Clinical diagnosis of Alzheimer's disease: report of the NINCDS-ADRDA Work Group under the auspices of Department of Health and Human Services Task Force on Alzheimer's Disease. Neurology 1984;34:939-944.

17 McKeith IG, Dickson DW, Lowe J, Emre M, O’Brien JT, Feldman H, Cummings J, Duda JE, Lippa C, Perry EK, Aarsland D, Arai H, Ballard CG, Boeve B, Burn DJ, Costa D, Del Ser T, Dubois B, Galasko D, Gauthier S, Goetz CG, Gomez-Tortosa E, Halliday G, Hansen LA, Hardy J, Iwatsubo T, Kalaria RN, Kaufer D, Kenny RA, Korczyn A, Kosaka K, Lee VM, Lees A, Litvan I, Londos E, Lopez OL, Minoshima S, Mizuno Y, Molina JA, Mukaetova-Ladinska EB, Pasquier F, Perry RH, Schulz JB, Trojanowski JQ, Yamada M; Consortium on DLB: Diagnosis and management of dementia with Lewy bodies: third report of the DLB Consortium. Neurology 2005;65:1863-1872.

-18 Emre M, Aarsland D, Brown R, Burn DJ, Duyckaerts C, Mizuno Y, Broe GA, Cummings J, Dickson DW, Gauthier S, Goldman J, Goetz C, Korczyn A, Lees A, Levy R, Litvan I, McKeith I, Olanow W, Poewe W, Quinn N, Sampaio C, Tolosa E, Dubois B: Clinical diagnostic criteria for dementia associated with Parkinson's disease. Mov Disord 2007;22:1689-1707.

19 Wenham PR, Price WH, Blandell G: Apolipoprotein E genotyping by one-stage PCR. Lancet 1991;337:11581159.

20 Combarros O, Alvarez-Arcaya A, Oterino A, Berciano J, Delgado-Rodríguez M, Peña N, Fernández-Viadero C, Luis Pérez-López J, Setién S, Carvajal A: Polymorphisms in the presenilin 1 and presenilin 2 genes and risk for sporadic Alzheimer's disease. J Neurol Sci 1999;171:88-91.

21 Di Natale M, Perri M, Kawarai T, Tomaino C, Sato C, Nacmias B, Shibata N, Sorbi S, St George-Hyslop PH, Bruni $\mathrm{AC}$, Rogaeva E: Absence of association between Alzheimer disease and the regulatory region polymorphism of the PS2 gene in an Italian population. Neurosci Lett 2003;343:210-212.

22 Gacia M, Safranow K, Gabryelewicz T, Styczyńska M, Pepłońska B, Dziedziejko V, Jakubowska K, Chlubek D, Zekanowski C, Barcikowska M: Two polymorphisms of presenilin-2 gene (PSEN2) 5' regulatory region are not associated with Alzheimer's disease (AD) in the Polish population. J Neural Transm 2008;115:85-90.

23 Gerrish A, Russo G, Richards A, Moskvina V, Ivanov D, Harold D, Sims R, Abraham R, Hollingworth P, Chapman J, Hamshere M, Pahwa JS, Dowzell K, Williams A, Jones N, Thomas C, Stretton A, Morgan AR, Lovestone S, Powell J, Proitsi P, Lupton MK, Brayne C, Rubinsztein DC, Gill M, Lawlor B, Lynch A, Morgan K, Brown KS, Passmore PA, Craig D, McGuinness B, Todd S, Johnston JA, Holmes C, Mann D, Smith AD, Love S, Kehoe PG, Hardy J, Mead S, Fox N, Rossor M, Collinge J, Maier W, Jessen F, Kölsch H, Heun R, Schürmann B, van den Bussche H, Heuser I, Kornhuber J, Wiltfang J, Dichgans M, Frölich L, Hampel H, Hüll M, Rujescu D, Goate AM, Kauwe JS, Cruchaga C, Nowotny P, Morris JC, Mayo K, Livingston G, Bass NJ, Gurling H, McQuillin A, Gwilliam R, Deloukas P, Davies G, Harris SE, Starr JM, Deary IJ, Al-Chalabi A, Shaw CE, Tsolaki M, Singleton AB, Guerreiro R, Mühleisen TW, Nöthen MM, Moebus S, Jöckel KH, Klopp N, Wichmann HE, Carrasquillo MM, Pankratz VS, Younkin SG, Jones L, Holmans PA, O'Donovan MC, Owen MJ, Williams J: The role of variation at AbetaPP, PSEN1, PSEN2, and MAPT in late onset Alzheimer's disease. J Alzheimers Dis 2012;28:377-387. 
Honda M, Kaname T, Igata-Yi R, Igata T, Hitoshi Y, Ogomori K, Miyakawa T, Yamamura KI: Novel intronic polymorphisms in the presenilin-2 gene and a case-control association study of Alzheimer's disease. Psychiatry Clin Neurosci 1999;53:579-585.

25 Quan W, Yasuda M, Hashimoto M, Yamamoto Y, Ishii K, Kazui H, Mori E, Kakigi T, Maeda K: Polymorphism of the regulatory region of the presenilin-2 gene in sporadic Alzheimer's disease: a case-control study. J Neurol Sci 2006;240:71-75.

26 Tanimukai H, Tsujio I, Hashimoto R, Kudo T, Kamino K, Shinozaki K, Takeda M: Presenilin-2 mutation and polymorphism in Japanese Alzheimer disease patients. Clin Chim Acta 1999;283:57-61.

-27 Liu Z, Jia J: The association of the regulatory region of the presenilin-2 gene with Alzheimer's disease in the Northern Han Chinese population. J Neurol Sci 2008;264:38-42.

28 Lebedeva E, Stingl JC, Thal DR, Ghebremedhin E, Strauss J, Özer E, Bertram L, von Einem B, Tumani H, Otto M, Riepe MW, Högel J, Ludolph AC, von Arnim CA: Genetic variants in PSEN2 and correlation to CSF betaamyloid42 levels in AD. Neurobiol Aging 2012;33:201.e9-e18.

-29 Howell WM, Brookes AJ: Evaluation of multiple presenilin 2 SNPs for association with early-onset sporadic Alzheimer disease. Am J Med Genet 2002;111:157-163.

30 Zhang J, Chen J, Xu Q, Shen Y: Does the presenilin 2 gene predispose to schizophrenia? Schizophr Res 2009; 109:121-129.

-31 Moskvina V, Harold D, Russo G, Vedernikov A, Sharma M, Saad M, Holmans P, Bras JM, Bettella F, Keller MF, Nicolaou N, Simón-Sánchez J, Gibbs JR, Schulte C, Durr A, Guerreiro R, Hernandez D, Brice A, Stefánsson H, Majamaa K, Gasser T, Heutink P, Wood N, Martinez M, Singleton AB, Nalls MA, Hardy J, Owen MJ, O’Donovan MC, Williams J, Morris HR, Williams NM; IPDGC and GERAD Investigators: Analysis of genome-wide association studies of Alzheimer disease and of Parkinson disease to determine if these 2 diseases share a common genetic risk. JAMA Neurol 2013;70:1268-1276.

-32 Piscopo P, Marcon G, Piras MR, Crestini A, Campeggi LM, Deiana E, Cherchi R, Tanda F, Deplano A, Vanacore N, Tagliavini F, Pocchiari M, Giaccone G, Confaloni A: A novel PSEN2 mutation associated with a peculiar phenotype. Neurology 2008;70:1549-1554.

-33 Raciti L, Nicoletti A, Le Pira F, Andreoli V, Contrafatto D, Lanzafame S, Maci T, Gambardella A, Quattrone A, Zappia M: Presenilin-2 gene mutation presenting as Lewy body dementia? Neurol Sci 2011;32:533-534.

-34 Giovagnoli A, R.Marcon G, Giaccone G, Confaloni AM, Tagliavini F: Cognitive deficits in familial Alzheimer's disease associated with M239V mutation of presenilin 2. Dement Geriatr Cogn Disord 2006;20:238-243. 